\begin{tabular}{l|l} 
REVISTA & $\begin{array}{l}\text { Revista Educación } \\
\text { ISSN: } 0379-7082 \\
\text { ISSN: 2215-2644 } \\
\text { revedu@gmail.com } \\
\text { Universidad de Costa Rica } \\
\text { Costa Rica }\end{array}$
\end{tabular}

\title{
Teatro para la memoria: danzantes de pensamientos
}

\author{
Camelo Gómez, Michael Steven; Jiménez Quenguan, Myriam \\ Teatro para la memoria: danzantes de pensamientos \\ Revista Educación, vol. 45, núm. 1, 2021 \\ Universidad de Costa Rica, Costa Rica \\ Disponible en: http://www.redalyc.org/articulo.oa?id=44064134028 \\ DOl: https://doi.org/10.15517/revedu.v45i1.42261
}

\section{(c) $(1) \Theta(\Theta$}

Esta obra está bajo una Licencia Creative Commons Atribución-NoComercial-SinDerivar 3.0 Internacional. 
Artículos Científicos

\section{Teatro para la memoria: danzantes de pensamientos}

Theater for Memoirs: Dancing and Beliefs

Michael Steven Camelo Gómez

Secretaria de Educación, Colombia

DOI: https://doi.org/10.15517/revedu.v45i1.42261

stevencamelogomez@gmail.com

Redalyc: http://www.redalyc.org/articulo.oa?id=44064134028

(DD http://orcid.org/0000-0001-5212-5620

Myriam Jiménez Quenguan

Universidad Santo Tomás, Colombia

myriamjqsigloxxi@gmail.com

(DD http://orcid.org/0000-0003-0807-6037

Recepción: 21 Junio 2020

Aprobación: 03 Octubre 2020

\section{ReSUMEN:}

Este artículo trata sobre el Teatro para la Memoria, proyecto desarrollado en Cumbal-Nariño (frontera colombo-ecuatoriana) (2016). Su propósito es fortalecer el legado ancestral en personas jóvenes indígenas a través de la danza y el teatro; en este sentido, sustenta la vigencia e impacto del Teatro del Oprimido de Augusto Boal, heredero de la pedagogía de Paulo Freire. Bajo un paradigma cualitativo, de estudio etnográfico y de acción participación, se trabajó con grupos focales que comunicaron creativamente lo que son, hacen y sienten por medio de bitácoras, mingas de pensamiento, memorias visuales, montajes escénicos y la creación de la obra El retorno de las perdices. Los resultados permiten afirmar que propuestas artísticas con jóvenes de cualquier comunidad cultural generan mayor sentido de pertenencia de su cuerpo, mente y voz para expresarse ante la sociedad, reivindicar su lugar en el mundo y otorgar mayor sentido a la historia de los pueblos. Esta experiencia se divulgó en distintas ciudades de Colombia, compartiendo la espiritualidad, historia y fuerza de los Pastos, también se pronunciaron algunas desigualdades, ya que al ser fronterizos y aislados de la capital, han padecido diferentes formas de inequidad. Finalmente, se reflexiona sobre la técnica teatral del Teatro-Danza, que en este caso integra etnoliteratura, arte y educación propia para apoyar una transformación positiva de problemas.

Palabras Clave: Los Pastos, Teatro indígena, Memoria de Cumbal, Mingas de pensamiento, Pedagogía del oprimido, Teatro - Danza.

\section{Abstract:}

Teatro para la Memoria (Theatre for Memory), was developed in Cumbal - Nariño (Colombian-Ecuadorian border) in 2016 to teach indigenous youth about their ancestral legacy and cultural traditions through dance and theater. The project is underpinned by the impact of Brazilian dramatist Augusto Boal's Theater of the Oppressed, which reflects the teachings of his mentor, educator, Paulo Freire. The project adhered to a qualitative paradigm and ethnographic study that included the interactive participation of the focus group participants. The group participants communicated creatively regarding who they are, what they do and how they felt, recording it in logs, known as "mingas of thought", visual representations of their memories through drama, exemplified in the collectively written, Return of the Partridges. The results show that art can inspire youngsters from any cultural community and instill them with a greater sense of ownership of their bodies, minds and voices so they can better connect with society, claim their place in the world and provide express in society, vindication of their place in the world and make the stories of their community more meaningful. This experience was replicated among different cities in Colombia to share the spirituality, history and strength of the Pastos culture. It is noteworthy that this community stated having experienced social inequity as a result of their being a remote community, isolated from the capital city. Finally, a reflection is conducted on the Dance Theater technique which is part of ethnoliterature, art and education to provide a positive support mechanism for transforming problems.

KEYWORDS: Pastos, Indigenous Theater, Memory of Cumbal, Mingas of Thought, Pedagogy of the Oppressed, Dance Theatre. 


\section{INTRODUCCIÓN}

Aquí se presentan los resultados investigativos del proyecto Teatro para la Memoria-Danzantes de Pensamientos, realizado en el municipio de Cumbal, al sur de Colombia. Desde 2015 se contactó a personas jóvenes indígenas, estudiantes de la Institución Educativa Agroecológica y algunos egresados ${ }^{[1]}$ de la misma institución de la vereda Cuetial; comienzos de 2016 se socializó la propuesta ante la comunidad y se concertó trabajar durante todo el año. Principalmente, se tuvo en cuenta los aportes teóricos y prácticos del Teatro del Oprimido de Augusto Boal, se buscó desde la educación artística posicionar la memoria de un pueblo en las personas jóvenes, y permitirles expresar sus realidades a través del cuerpo, porque en este tipo de población se "descubren aspectos que llevan a la alienación, y en el lenguaje los aspectos que lo convierten en instrumento de manipulación” (Vasco, 1994, p. 23). Por esta razón, el teatro y la danza funcionaron como rutas de expresión y liberación.

El objetivo principal fue fortalecer procesos de memoria colectiva en jóvenes del pueblo de los Pastos, Resguardo del Gran Cumbal, quienes vivenciaron una serie de talleres de teatro y danzas como estrategia de resistencia frente al distanciamiento de prácticas ancestrales. Al comienzo se detectó en ellos un frágil conocimiento sobre su historia, cosmovisión o mitos de su pueblo, indiferencia a las problemáticas de su comunidad, poco interés por las memorias de su territorio, escasa participación en asambleas o fiestas del resguardo indígena.

Las personas jóvenes son la esperanza del mañana, tienen la obligación histórica con su pueblo de seguir ejerciendo sus propios mandatos ${ }^{[2]}$, y hacer de su cultura una huella imborrable e imprescindible en el devenir latinoamericano. Así lo han hecho generaciones anteriores que en su momento se encargaron de mantener a sus pueblos con la frente en alto, pero los legados de más de 500 años de sometimiento colonial-cristiano y de leyes injustas contra las personas indígenas, han sembrado el miedo, los ha hecho escapar como sujetos migrantes ${ }^{[3]}$ hacia las ciudades y modificar sus expresiones culturales, lo que ha debilitado la apropiación juvenil en la organización social.

Con base en dichas problemáticas, se quiso promover una estrategia educativa que sirviera para encender memorias y difundirlas en diferentes escenarios culturales; pero, ¿Cómo involucrar los intereses y gustos juveniles? ¿Cómo motivar a las personas jóvenes a investigar sobre memorias de su pueblo y legados culturales? ¿De qué manera promover espacios de encuentro que legitimen al joven como sujeto social? Para dar respuesta se destinó el Teatro del Oprimido, cuyos resultados han sido emancipadores en diversos territorios colombianos y latinoamericanos, este plantea la necesidad de una técnica y un contenido que se adapte al contexto. .El teatro es una forma de comunicación entre los hombres; las formas teatrales no se desarrollan porque sí, de manera autónoma, sino que corresponden siempre a necesidades sociales bien determinadas y a momentos precisos" (Boal, 1974, p. 11). Este estudio sintetiza tres insumos principales: Memoria Colectiva desde la concepción del pueblo indígena de los Pastos; Teatro del Oprimido, propuesta de Boal y la Educación Popular, por el póstumo maestro Paulo Freire.

Este artículo parte de la problemática expuesta en torno a la memoria colectiva indígena y está compuesto de cinco partes, la primera ¿Desde dónde partir? Antecedentes, presenta un estado del arte que da cuenta de estudios relevantes en torno a la problemática del teatro indígena. En la segunda parte se encuentra el Marco Teórico, que expone el aparato crítico y conceptual de esta investigación, siendo Freire y Boal, los principales referentes. En la tercera parte ¿Cómo atravesar rutas?: Metodología, se presentan los caminos que condujeron a la creación de una obra de teatro-danza colectiva, en esta parte se explica el paradigma, el tipo de estudio, los criterios de selección de la población, las estrategias implementadas y el trabajo a través de grupos focales. También se explican los diferentes instrumentos de recolección utilizados como: las bitácoras y los talleres, las memorias fotográficas, la creación y montaje escénico y las mingas de pensamiento. Además, se muestra cómo se constituyó el grupo teatral con las personas jóvenes indígenas Pastos, denominado Danzantes de pensamientos, quienes con la participación de su comunidad (Cumbal) 
escribieron y representaron su propia obra de teatro, El retorno de las perdices. Para el análisis de los resultados, se tienen en cuenta las cuatro fases del Teatro del Oprimido denominadas: La seducción del teatro danza, Guion de la obra del grupo de teatro indígena, Rememorando la historia de los Pastos y Mingando se construye colectividad. La cuarta parte la constituyen los Resultados, que integran lo más representativo de las fases anunciadas, y en la quinta parte se incluye un apartado de Discusión y conclusiones de lo más representativo de esta experiencia creativa y su proceso. A continuación, la persona lectora encontrará el desarrollo de cada una de estas partes.

\section{¿DESDE Dónde PARTIR? ANTECEDENTES}

Las memorias de los pueblos han sido manipuladas, distorsionadas y masacradas; la colonización, el imperialismo y la globalización han marcado en América Latina escenarios de miedo y olvido. Por esto es importante acudir a la memoria, "la cual, al constituirse con base en las articulaciones de identidades colectivas, favorece la creación de movimientos y la producción de representaciones sociales que permitan nuevas significaciones" (Méndez, 2005, p. 3). Para Rama (2004) cada aventura o experiencia se plasma en testimonios, fenómeno frecuente en el Abya Yala, que se consolidan como género literario. Al relatar las memorias y testimoniar experiencias grupales, el aprendizaje es más significativo; la Oralidad, el Relato y el Testimonio hacen parte de los aportes literarios que predominan en Latinoamérica, son expresiones contra hegemónicas-culturales que se materializan en la escritura.

Sobre el universo teatral prehispánico existen diversos estudios que dan cuenta de la existencia de obras indígenas y su particular cosmovisión, así lo destaca Henríquez (2009) al referirse a obras mayas, nahuatles y quechuas. Aunque en el siglo XIX algunas se traducen a la escritura occidental, lo que tienen en común es el predominio de la oralidad, esto hace parte de su legado, de su camino, de sus mitos y de su memoria. La oralidad se transforma en palabra, en canto, pero:

Estas formas de conservar el pasado, basadas en la supremacía de lo oral de la palabra y apoyadas en sistemas de escritura no alfabéticos, experimentaron a partir de 1492 diversas modalidades de censura y cautiverio de parte de la cultura dominante (Henríquez, 2009, p. 82).

De esta manera, la diferencia indígena pasó a interpretarse de forma negativa e incluso bárbara; la visión colonialista difundió una lectura errónea, basada en una lógica de la dominación patriarcal y la negación corporal; el eurocentrismo sólo reconocía las escrituras alfabéticas, lo que estaba fuera de ese modelo podía considerarse bárbaro. Habría que seguir cuestionando cómo se sigue reproduciendo la colonización del lenguaje y de la memoria, y cómo el teatro se ha constituido en una forma de resitencia de los pueblos. La danza, la música, la poesía, el simbolismo de la flor y del canto son para culturas como la Náhuatl, una forma de conectar con lo divino. La misma autora en Teatro maya: Rabinal Achi o Danza del Tun (Henríquez, 2007), alude a esta obra, puesta en escena desde el siglo XIII hasta la actualidad y reconoce cómo para los pueblos indígenas, la escritura se hace con el cuerpo y se convierte en ritmo, en danza, en poesía.

Mignolo (1992), reconocido investigador del sistema y del imaginario colonial, sostiene que no existe Modernidad sin colonialismo e injusticias; el llamado Nuevo Mundo fue entendido como la novedad que había que alfabetizar; los colonos se encontraron con una pluralidad de formas discursivas para dominar. Para Foucault (1992), “en toda sociedad la producción del discurso está a la vez controlada, seleccionada y redistribuida" (p. 5) por poderes y peligros para dominar.

En América Latina, uno de los países con más estudios sobre culturas indígenas es México; según Adame (2006), allí el teatro indio preserva la cultura y su transformación, distingue el teatro comunitario del teatro subvencionado, "considero que cualquier intento por acercarse al teatro indio y comunitario debe tener en cuenta el sentido que para las propias comunidades tienen las representaciones." (p. 22). No se trata entonces de un espectáculo, sino de un campo lleno de energía y significaciones, porque se entiende que la comunidad 
es un ser complejo, en ella se comparten aspectos culturales, sociales, religiosos, estéticos. Lo interesante sería descubrir qué es lo que produce en ella la cohesión y la unidad, más allá de las diferencias. En este sentido, el teatro indígena es complejo, es una propuesta ecopoiética, integra multiplicidad de representaciones, lo pluricultural y lo sagrado; es un arte que produce transformación social y espiritual. Para las personas indígenas la creación es liberadora e inagotable, es una forma de reconocer la autonomía espiritual de cada persona.

Araiza (2009) distingue entre el universalismo y el relativismo, destaca que el teatro indígena contemporáneo ha servido para integrar lo indígena al concepto de nación. La dificultad la encuentra en la concepción occidental del teatro que considera, no sin una carga de prejuicio, que eso no es teatro; lo que pasa, dice, es que la función del teatro indígena es altamente simbólica, comunitaria, sagrada, se fusiona con el juego y la fiesta de los pueblos. Sugiere invertir el etnocentrismo cultural a favor del teatro indígena, pues es necesario reconocer el valorar de los pueblos y sus contextos, porque el arte es universal y es también una forma de conocimiento.

Según la tradición oral, el poblamiento de Cumbal (Nariño, sur de Colombia) surge gracias a la unión entre el Nevado de Cumbal y la laguna la Bolsa. La vida surgiría en el sitio denominado la piedra del Wacamullos, ubicada en el sector Guacaltud, en la Vereda Tasmag. Existen algunas narraciones mitológicas sobre el momento en que en este territorio indígena se inicia la liberación de tierras que habían sido usurpadas por los españoles. Para Chirán y Puenguenan (2015), en el siglo XX se dieron algunas luchas por la recuperación de tierras, como la sucedida en 1973 que implicó gestiones en Quito, Popayán y Bogotá; finalmente, los pueblos nativos lograron recuperar por vía legal, parte de su territorio ancestral, recobraron el Llano de piedras, la hacienda el Zapatero, el Laurel y la Boyera, así las familias indígenas o el cabildo se convirtieron en propietarios, antes fueron jornaleros de patrones españoles. Según la Alcaldía Municipal de Cumbal (2016), el Resguardo tiene una población total censada de 37.635 habitantes, se distribuye en ocho veredas: Guan, Tasmag, Cuaical, Quilismal, Cuetial, Cuaspud, Boyera, San Martín y Miraflores. La población Indígena es de un $93 \%$, a pesar del despojo de tierras y los sometimientos que han afrontado a lo largo de la historia, mantiene parte de su identidad cultural.

En las investigaciones sobre los pueblos precolombinos sobresale un símbolo común: el sol para los Pastos, igual que para la cultura Maya, se representa con varias puntas. Kauffmann (1980), en su Manual de Arqueología Peruana, explica que fuera del territorio Andino, entre la culturas mesoamericanas, también se encuentra una estrella de ocho picos que forma el calendario solar Azteca o Piedra del Sol. El sol prehispánico comunica una visión geométrica sagrada ligada a los ciclos de la vida, un saber cósmico de asombrosa proporcionalidad.

Algunas propuestas artísticas asumen la importancia de la memoria indígena, como la Danza y la Música, como estrategia pedagógica para el fortalecimiento de la micro historia del Municipio de Cumbal de Gustin, Insuasty y Benavides (2007); a través de talleres de danza y música reconstruyen saberes ancestrales con estudiantes de octavo grado, logran dialogar con la cultura local y reconocen la necesidad de integrar en la educación visiones de mundo y realidades históricas propias, expresadas en lenguajes corporales. En Tejiendo pensamientos para dinamizar los saberes propios de los Cumbales, Chirán y Puenguenan (2015) plantean que las instituciones educativas en Cumbal no han desarrollado suficientes pedagogías que vinculen saberes propios; sugieren que la minga puede contribuir a la conservación de la cultura y a la generación de conciencia colectiva.

Campion (2015), en Entre la memoria histórica y el atentado: las relaciones transfronterizas de los indígenas Pastos del Nudo de Waka, describe la historia de dominación territorial, la creación del Plan Estratégico Binacional del Pueblo Pasto y las relaciones fronterizas carentes de atención estatal. Sostiene que en el Municipio de Cumbal existen lazos con el hermano país (Ecuador), las fronteras realmente no existen; surge así el concepto de territorio político, precisamente para favorecer la memoria autóctona. En esta misma línea, existen estudios en defensa de los pueblos aborígenes; a nivel internacional, la Universidad Autónoma de 
México, en Desafiando al Estado-nación: Reclamos de autonomía del pueblo Pasto, Carrión (2015) resalta la importancia de la reorganización territorial para que los Pastos sean autónomos; cuestionan las políticas marginales heredadas desde el racismo colonial que van en detrimento de la identidad y la memoria.

En lo concerniente al teatro como forma liberadora, existen distintos trabajos, para este estudio fueron esclarecedores los aportes de la Antropología Teatral que han tenido un impacto favorable en Colombia, propuestas como la de la Asociación Cultural y Ambiental Teatro Itinerante del Sol, apoyan la búsqueda de las raíces de las culturas aborígenes Latinoamericanas desde nuevas estéticas, como el Biodharma, que pretende integrar las artes escénicas con las demás artes y saberes de la naturaleza. En este sentido, es pertinente la publicación de Monsalve (1995), El Baile del Muñeco, que desvela los ritos de fecundidad celebrados en las fiestas de la región de los ríos Apaporis, Miritipaná y Caquetá, allí sobresalen danzas, cantos y prácticas culturales propias, que dieron origen al Teatro de la Memoria, y que sin duda aportaron ideas e instrumentos para esta investigación.

\section{Marco Teórico}

La posibilidad de conocer el pasado a partir de recuerdos colectivos, remite a experiencias para transmitir huellas en espacios y tiempos, donde las prácticas o tradiciones comunes se reviven desde la voluntad y necesidad de re-existir. Halbwachs (1968) plantea que "no sólo las casas y las murallas perduran a través de los siglos, sino toda la parte del grupo que no deja de estar en contacto con ellas" (p. 135). Se entiende que hay ciertas vibraciones que permanecen silenciosas en la vida de un grupo y al evocarlas en el tiempo, despiertan pensamientos y unidad. Dicho tiempo vive en quienes se apoyan y recomponen desde los recuerdos. Frente a ello, hay que disponerse a la amplia diversidad en todas sus esferas, para comprender las dinámicas de cada cultura, "se piensa que la diversidad étnica y cultural es positiva para una sociedad y que hay que fomentarla o, al menos, protegerla" (Pichardo, 2009, p. 39).

La memoria colectiva que mantiene viva la llama de los Pastos "es célula de conocimientos los cuales están recreados en la oralidad, los mitos, el ritual, la festividad, la shagra, el fogón, el telar, los petroglifos o lugares cosmoreferenciales" (Shaquiñan y Ministerio de Ambiente y Desarrollo Sostenible, 2012, p. 3). Es por ello que se despertó en jóvenes la necesidad de recrear, asumir y reproducir, ya que "mediante la memoria se recapitulan los antecedentes de la naturaleza y el cosmos, de allí se orienta la visión en el shaquiñán de la vida" (Shaquiñan y Ministerio de Ambiente y Desarrollo Sostenible, 2012, p. 3). La característica principal de sus memorias es que no son escritas, sino que se representan en lugares, elementos, prácticas cotidianas y son documentos del presente que reflejan simultáneamente el pasado.

El rito trasciende para que las memorias se conecten con su espiritualidad, pues propaga "sus actos, potencias, virtudes, capacidades y sus facultades, como intermediarios entre lo humano terrenal, con las energías naturales y cósmicas" (Shaquiñan y Ministerio de Ambiente y Desarrollo Sostenible, 2012, p. 3), pero el peso simbólico trata de ser negado, ya que "la naturaleza de la sociedad capitalista implica un proceso creciente de enajenación e imposición cultural sobre el mundo subalterno, al que se quiere ver convertido en un consumidor de cultura y no en creador de ella" (Bonfil, 1991, p. 49).

El Teatro del Oprimido es método de transformación, ya que propone un teatro que aumenta espacios pedagógicos, que mejora las condiciones locales de la población. Inicialmente se refiere al Teatro de la Crueldad que "ha sido creado para devolver al teatro una concepción de la vida apasionada y convulsiva" (Artaud, 1978, p. 199) mediante el uso de elementos cotidianos que posibiliten la creación de escenas, que muchas veces cobrarán tintes sanguinarios, pero que corresponden a realidades contemporáneas. $\mathrm{La}$ intención de este teatro es despertar emociones en los espectadores, quienes observan su realidad en escena, reflexionan sobre la caótica crueldad del ser humano y tratan de modificar su contexto, "el Teatro de la Crueldad intenta recuperar todos los antiguos y probados medios mágicos de alcanzar la sensibilidad" (Artaud, 1978, p. 199). De la mano de esta propuesta se enmarca el Teatro del Oprimido, que 
nace de la experiencia del Teatro de Arena en Brasil, con perspectiva de brindar al pueblo herramientas para dejar de ser espectador y situarlo como actor de su propia historia; tomó impulso en América Latina en las décadas de los años 60 y 70, como método de comunicación de sectores populares, donde había reflexiones implícitas tanto teóricas como prácticas.

En 1973, Boal aporta a los procesos artísticos del Perú en medio de su exilio, propuso que los pueblos debían asumirse como protagonistas del cambio social en la acción dramática y para ello se necesitaba devolver los medios de producción del teatro desde la construcción del mismo humano; "un lenguaje apto para ser utilizado por cualquier persona tenga o no aptitudes artísticas (...) esto implica una poética del oprimido, es decir una opción ético - política de hacer teatro" (Boal, 1980, p. 17). De esta forma, configura nuevos ejercicios y juegos teatrales que implican el trabajo corporal y la expresión, para lo que Boal (1980) propone cuatro momentos en el arte de la interpretación: conocer el cuerpo y elevar grados de consciencia sensorial, las posibilidades corporales y deformaciones; la segunda etapa donde por medio de juegos se desarrolla la capacidad expresiva. En la tercera etapa, la persona espectadora interviene en escena y modifica su desenlace o la categoría que Boal asignó: Teatro Foro. Por último, la creación de formas sencillas para representar realidades concretas con Teatro Periodístico, Teatro Invisible, Teatro Fotonovela, etc.

El Teatro del Oprimido ofrece a cada uno el método estético para analizar su pasado, en el contexto de su presente y para poder inventar su futuro. Este teatro ayuda a los seres humanos a recuperar un lenguaje que ya poseen - aprendemos cómo vivir en sociedad jugando al teatro, cómo sentir, sintiendo; cómo pensar, pensando; cómo actuar, actuando, es un ensayo para la realidad. (Boal, 2004, pár. 10)

En esa dinámica artístico - creadora, Brecht impulsa la idea de un teatro politizado, que es pertinente para sentar posturas sobre situaciones reales del contexto, donde se ha impuesto la violencia estatal, "principalmente tratase aquí de una tentativa de mostrar efectos revolucionarios que ejerzan dialéctica dondequiera que se muestre y su papel de óptima enterradora de las ideas e instituciones burguesas" (Brecht, 1972, p. 24). Estas intenciones cobran vigencia para cimentar escenarios artísticos de diálogo que materialicen lazos de solidaridad y generen aprendizajes para la vida, transformaciones del ser en lo cotidiano, en la posibilidad de construir personas críticas y libertarias con la tierra, donde se piense un futuro digno para vivir, sentir y sonreír. Los tres autores se refieren a la construcción de un nuevo método teatral y proponen situaciones que cuestionan sobre la función como artistas - creadores, además brindan posibilidad de pensar escenarios artísticos no convencionales.

La propuesta educativa está enmarcada en horizontes ético-políticos desde planteamientos del maestro Paulo Freire, quien fundamenta en América Latina una propuesta educativa de carácter estructural, donde haya para todas las clases sociales una mayor posibilidad de participación y emancipación: la Educación Popular. Con este método, las personas toman conciencia de sus condiciones de desigualdad en un sistema opresor y fijan su rumbo en el horizonte de la dignidad, las personas docentes son indispensables en este proceso, ya que guían a las estudiantes, su rol es descolonizar o en palabras de Freire (2005) aquel que "al identificarse, desde con los educandos, debe orientarse en el sentido de la liberación de ambos. . . su acción debe estar empapada de una profunda creencia en los hombres. Creencia en su poder creador" (p. 83). Resalta la importancia de poseer grados de conciencia social, un uso de la experiencia ${ }^{[4]}$ para educar, cuya correspondencia permite la transformación de miradas frente al mundo, una nueva concienciación ${ }^{[5]}$, que empodera en las prácticas cotidianas de libertad.

Para trascender los esquemas corporales y mentales impuestos, Freire plantea, en la Pedagogía del Oprimido (2005), que la conquista del mundo para la liberación de las personas es a través del diálogo, posible "si hay un profundo amor al mundo y a los hombres. No es posible la pronunciación del mundo, que es un acto de creación y recreación, si no existe amor que lo infunda" (p. 108). Reconocer las múltiples capacidades autónomas de las comunidades es "constancia de la diversidad cultural que reenvía a una cuestión de justicia social y de distribución del poder, que es un asunto de igualdad” (De Lucas, 2009, p. 6). 
Zuleta (2010) considera que la educación es parte fundamental en el fortalecimiento de la identidad cultural, ya que una verdadera enseñanza debe partir de la experiencia del alumnado, para mostrarles que todo su medio educa, se problematiza y así crean herramientas para resolver conflictos identitarios, por ello se encaminaron procesos que reivindicaron la cultura desde La Ley de Origen o Derecho Mayor, base primordial para cualquier proyecto educativo en los pueblos indígenas, ya que describe las raíces originarias y constituye los principios que rige cada pueblo para mantener el equilibrio y la armonía, grupos étnicos "considerados como una forma de organización social por autoadscripción. A partir de ahí se crean identidades étnicas que permiten categorizarnos a nosotros mismos y al resto para interactuar" (Pichardo, 2009, p. 38).

De la mano, el proyecto de educación propia es una alternativa de resistencia frente a dinámicas homogeneizadoras que transforman a las personas jóvenes en consumidoras de un sistema económico devastador, es decir, revalúa el denominado mundo del progreso que, en un largo periodo de tiempo, hizo que la educación fuera potestad de la iglesia, que se impidieran las lenguas indígenas y que sus fines fueran ajenos a intereses en las comunidades, desligando concepciones de mundo. Es así que se considera prioridad en esta propuesta educativa, el pluralismo que "deriva de ser un valor muy vinculado a la igualdad y a la libertad, pues su violación se suele concretar en una interferencia de los poderes públicos que impide o dificulta el acceso a una participación política, sindical, cultural" (De Lucas, 2009, p. 7).

\section{¿Cómo atravesar diversidad de rutas?: Metodología}

Desde un paradigma cualitativo se profundizó en las cualidades de la población y en la recuperación de su tradición; tanto las personas investigadoras como las jóvenes involucradas, usaron "palabras artísticamente para acercarse a sus experiencias y convertirlas en guías por caminos desconocidos” (Ferreiro, 2012, p. 43). Bajo un enfoque de carácter crítico-social $^{[6]}$, y un tipo de estudio etnográfico de investigación-creación ${ }^{[7]}$, se diseñaron diversas técnicas de recolección de información (28 talleres, fotografías, entrevistas, bitácoras y el montaje escénico -guion colectivo, caracterización de personajes, ambientación, etc.), que contribuyeron a reflexionar en torno a sus raíces y a "descubrir aquellas ataduras de esclavitud de las que somos todos víctimas más o menos inconscientes, buscar entonces liberar” (Vasco, 1994, p. 22). Este trabajo posibilitó escenarios para representar la memoria desde el cuerpo, la palabra y la acción (Figuras 1 y 2), la "Investigación

Creación" se entrelazó en esta propuesta, el proceso implicó creaciones performáticas colectivas "8], que "desde su responsabilidad ética aportan a la sociedad en su transformación” (Daza, 2009, p. 3). El arte fortaleció el tejido social - comunitario, fue capaz de ofrecer experiencias que trascendieron en el desarrollo interno y en las relaciones con otras personas, permitió potencializar la imaginación como escenario de autoconocimiento, autovaloración, curación, y tal como lo afirma Daza Cuartas (2009), es en esos escenarios posibles "un creador investigador, debe tener la capacidad de re-crearse a si mismo, constantemente, cambiar o mutar sus formas de ser, transformarse, saber hacer uso y experimentación de nuevas técnicas, trascenderlas hasta llegar a inaugurar el por-venir" (p. 90). 


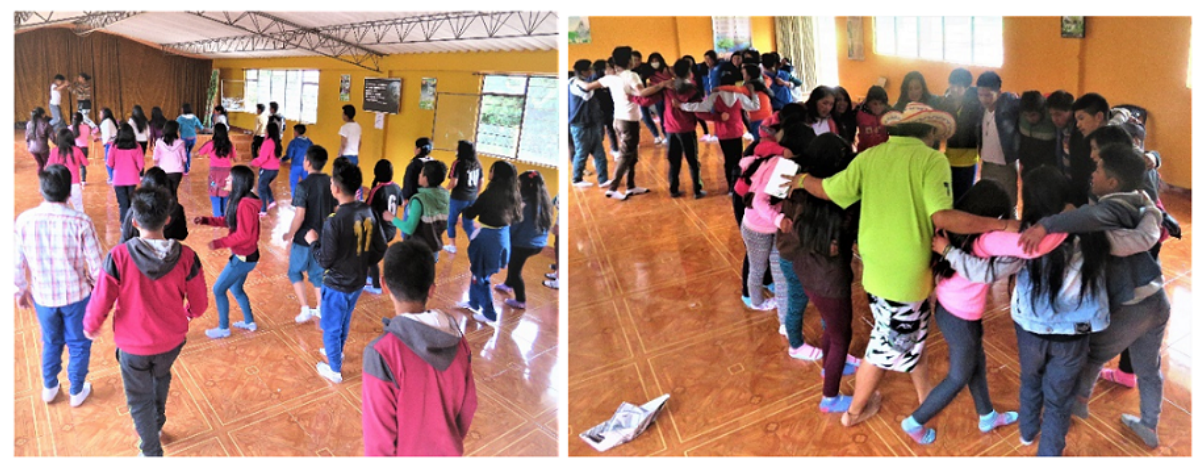

FIGURAS 1 Y 2

Grupo de Teatro Para la Memoria. Talleres de Danzas

Fuente: Archivo personal del equipo investigador, Cumbal, Nariño, Colombia, Marzo 2016

$\mathrm{Al}$ ser un proyecto innovador en Cumbal, en la convocatoria para participar hubo masiva asistencia, más de lo que se esperaba. Inicialmente se procedió a motivarles, el grupo reflexionó sobre su cultura y conoció diferentes técnicas del Teatro del Oprimido, como el teatro periodístico, teatro foro y teatro novela, pero ninguna llenaba la expectativa colectiva para la construcción de montaje. Por eso se realizó un show de talentos, en el que por pequeños grupos representaron sus habilidades, gustos e ideas para la consolidación de una obra de teatro. Esta experiencia diagnóstica y motivacional permitió encontrar la posibilidad estética del grupo mediante una técnica eficaz: la del Teatro-Danza, con énfasis en Las Danzas Andinas, ${ }^{[9]}$ se consolidaba así como propuesta común que agitó el grupo, lo que emocionó e inspiró sonrisas. De esta manera, el universo investigativo lo constituyeron 40 jóvenes indígenas entre los 14 y 19 años, algunos cursaban secundaria en la Institución Educativa Sagrado Corazón de Jesús, Vereda Cuetial, Resguardo El Gran Cumbal y otros eran jornaleros; los criterios de inclusión tuvieron en cuenta la libre participación. Los talleres se impartieron a 5 grupos focales de trabajo, cada uno conformado por 8 jóvenes que realizaron sus propuestas e indagaciones reflejadas en las escenas -remembranza de hechos históricos y danzas andinas-, que posteriormente se articularon en la creación colectiva Danzantes de Pensamientos y su montaje escénico. También participaron dos personas docentes, uno de teatro, Michael Camelo y otra de danza, Argeny Chirán. El proyecto lo apoyaron las directivas de la institución educativa, padres y madres de familia y la comunidad de Cuetial, quienes siempre estuvieron en disposición para colaborar.

Esta investigación respetó la integridad científica y los criterios éticos, cumplió los protocolos exigidos por las entidades académicas, gubernamentales y poblacionales. Los principales beneficiarios fueron los y las adolescentes, la comunidad de Cumbal y la comunidad educativa de Nariño. Los fines fueron estrictamente artísticos, científicos, académicos y socioculturales. Para la recolección de todos los datos, previamente se realizó la firma del consentimiento informado, garantizando en todo momento su libre integración y el absoluto respeto a la integridad de cada participante, quien no fue sometido a ningún tipo de riesgo ni físico ni psicológico.

Proceso creativo. Este proyecto se puede replicar en poblaciones semejantes a la de este estudio. Las propuestas del Teatro del Oprimido pueden ser desarrolladas en cualquier territorio marginado o escenario popular, deben tener aprobación de la comunidad para tomar legitimidad ético-social ${ }^{[10]}$, por ello periódicamente, como una estrategia de acompañamiento, se organizaron mingas de pensamiento [11] , donde participaron personas indígenas adultas para conocer los avances en la práctica artística y aportar sugerencias. La reproducción se puede dar desde tres aspectos: 1) la innovación, que permite la apropiación juvenil de memorias ancestrales de los pueblos a través de escenarios artísticos y de comunicación liberadora; 2) como estrategia que involucra al joven de una manera más activa en dinámicas organizativas; 3) finalmente, para constatar que la etnoliteratura ${ }^{[12]}$, pretende aproximarse a las raíces de los pueblos para encontrar 
aquello que defina y explique el estar en el mundo, reconoce las múltiples diversidades para encontrar una verdadera identidad. Para Zuñiga (1993) en los aportes etnoliterarios, la fantasía cumple una función vital en las formas de expresión humanas, “a través de las cuales se expresan, buscando la oscilación entre observación y emoción. Emoción que es participación vital, apertura frente al OTRO, comprensión del YO a partir de ÉL, de las diferencias. Unidad en la pluralidad" (p.156).

Extrayendo la información. Los principales instrumentos de recolección de información consistieron en: bitácoras personales, talleres, fotografías (de los talleres y los montajes escénicos) y mingas de pensamiento (entrevistas, conversaciones), que contribuyeron al cumplimiento de los objetivos.

Bitácoras y talleres: las personas artistas en formación expresaron en escritos quincenales sus sentires, posiciones y aprendizajes más significativos de las sesiones de trabajo. La escritura sistemática durante la experiencia educativa permitió que cada participante redactara un cuaderno con talleres-bitácoras sobre la reconstrucción de las memorias de su pueblo y que desarrollara la habilidad comunicativa ${ }^{[13]}$ lecto-escritora. La escritura es considerada como una vía para la memoria, ya que consolida datos que pueden permanecer en el tiempo, en este caso también se tomó la criticidad ${ }^{[14]}$ como característica esencial, ya que reflexionaron constantemente sobre su contexto; esta actividad "facilita el desarrollo de formas de pensamiento propias, vinculadas con la escritura, como la búsqueda de objetividad, el razonamiento científico o la capacidad de planificación del discurso (poder avanzar y retroceder en él)” (Cassany, 2008 p. 90).

Memorias fotográficas: la imagen brinda la posibilidad de revivir momentos para ser interpretados con mayor rigurosidad; el cuerpo, las expresiones, los sentimientos y las propuestas colectivas se presentan en forma estática para su análisis. Sin embargo, "todo parece indicar que no hay un equilibrio entre el gran protagonismo de la fotografía en la sociedad y la poca atención que merece su estudio desde la investigación social” (Aguayo y Roca, 2005, p. 9). La fotografía se convirtió en una herramienta cualitativa, válida en la recolección de datos y en documento visual como fuente primaria de investigación social. Las fotografías de cada encuentro permitieron una lectura constante de las posturas corporales, expresiones y representaciones colectivas que iban logrando. También ayudaron para que las personas jóvenes reconocieran sus dificultades detectadas en las imágenes, trabajaban en ello y las corregían en escena. La Figura 3 muestra como cinco guerreros blancos que cuidan el territorio de los Pastos, iban tomando posturas, expresiones faciales y posiciones de guerra con maquillaje adaptado para ello; también se refleja el fruto del trabajo en equipo y la apropiación de personajes. Se ven sigilosos, muestran furia, estrategia de ataque y defensa en manada. Vienen de las montañas, cuidan el volcán, los verdes frutos de Cumbal y la vida espiritual.

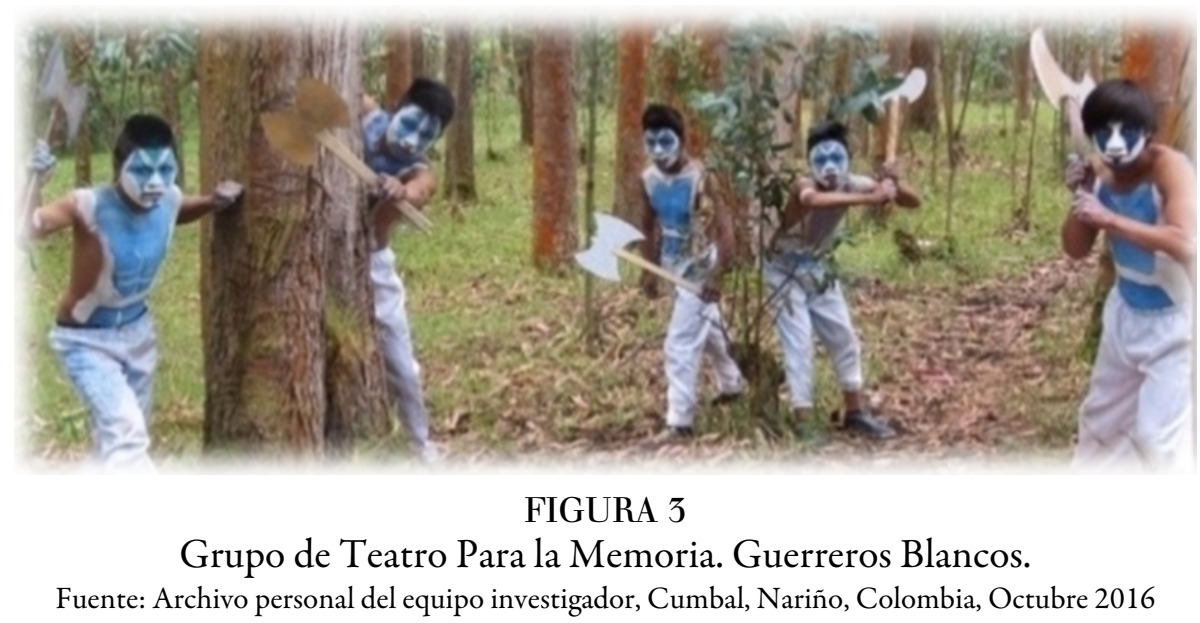

Creación y montaje escénico: para el montaje se creó y representó un guion para la reconstrucción colectiva de memoria, desde los alcances del Teatro del Oprimido como alternativa pedagógica de cambio social. La obra fue presentada tanto en escenarios educativos de Cumbal como en las ciudades de Pasto y 
de Cali. En las sesiones de trabajo se desarrollaron capacidades corporales como agilidad, fuerza, equilibrio, que permitieron la personificación, representación y apropiación de elementos simbólicos de su cultura. Se crearon cuatro escenas del guion Danzantes de Pensamientos que vislumbraron diferentes escenarios creativos. En el transcurso de la creación del montaje escénico sobre memorias del Pueblo Indígena de los Pastos, siempre hubo interacción y diálogo con la comunidad; las personas jóvenes artistas indagaban a los mayores para conocer sobre su historia, mitos y relatos fantásticos del pueblo; recorrían sitios considerados sagrados y abrían sus mentes para sentir las espiritualidades presentes en el territorio. Mary ${ }^{[15]}$ de quince años de edad, comenta que "impulsaron tanto nuestros talentos, aprendimos de nuestra gente, nuestros vecinos, todo eso que es de nuestra cultura como la Viuda ${ }^{[16]}$, la moledora ${ }^{[17]}$, el inti raimy o los duendes. Esos conocimientos de nosotros los Pastos" (comunicación personal, 10 de noviembre, 2016). La búsqueda fue ampliada con la consulta de textos en la Casa de la Juventud, en el Cabildo y la Biblioteca Municipal, el fin era profundizar en las propias visiones y saberes de su cultura. Esta experiencia formó un positivo posicionamiento juvenil con respecto a sus raíces.

Las cuatro escenas creadas reflejan la espiritualidad indígena, su historia, simbología, legados culturales y la resistencia de los Pastos. Los personajes fueron una construcción crítica, las actrices y los actores asumieron la responsabilidad como facilitadores de conocimiento cultural e histórico, "Valoramos más nuestro pueblo, lo que uno tiene alrededor. Ahora nos queda es saberlo mantener, saberlo hablar con la gente que conozcamos" (Cuastumal, comunicación personal, 21 de junio, 2016). Así nació el "Grupo de Teatro: Danzantes de Pensamientos" y su montaje escénico, que logró reconocimiento tanto a nivel local como nacional; el grupo se gestó dentro del resguardo indígena de Cumbal, contribuyó a ampliar horizontes de incursión e inclusión, permitió direccionar procesos educativos de raíz en el marco del gran proyecto de Educación Propia. De manera más interna, se fortalecieron las habilidades, potencialidades estéticas y creación colectiva.

Las Mingas de pensamiento: proceden de la tradición Quechua, los habitantes de un lugar se escuchan y conversan con la finalidad de llegar a consensos sobre la realización o evaluación de un trabajo para el bienestar comunitario. El bien común es el que convoca para valorar, apoyar y organizar, en este caso un montaje escénico que visualiza su memoria, principios, espiritualidad, riqueza simbólica, su vida. Este instrumento fue esencial para lograr diálogos con la comunidad y validar el trabajo con las personas jóvenes. Gracias a las mingas se promovió el autoconocimiento, la solidaridad, el compañerismo, el trabajo en equipo, el liderazgo, sentido de pertenencia y amor por su cultura. El teatro-danza pasó a convertirse en la voz de familias, personas mayores, jóvenes, docentes, investigadoras y vecinas, quienes participaron animadamente en una creación que las incluye y representa. "El grupo se dio a conocer en el resguardo por mostrar nuestra cultura y la historia. Nuestros legados, formas de vestir, fiestas propias, pues hasta las creencias" (Colimba, comunicación personal, 10 de noviembre, 2016).

En una entrevista realizada en la minga de pensamiento al final del año 2016, Edison Chinguad -18 años y Gobernador del Cabildo Estudiantil-, afirmó que

la experiencia de pertenecer a un grupo de teatro es inolvidable, llena de aventuras y conocimiento, nunca pensé llegar a presentarme en tan bonitos escenarios, se aprende de lugares muy lindos con diferentes creencias, estilos de vivir y formas de vestir" (comunicación personal, 10 de noviembre, 2016).

¿Cómo analizar? El análisis de la información recolectada se fundamenta a través de la observación participante, la identificación de recurrencias, y la interpretación de datos significativos desde la reflexión pedagógica y estética del "oprimido", que metodológicamente se divide en las 4 fases: La Seducción del Teatro-Danza; Guion de la obra del grupo de teatro "Danzantes de Pensamientos"; Rememorando la historia de los Pastos; y, Mingando se construye colectividad. 


\section{Resultados}

El proceso investigativo caracterizó, analizó e interpretó la información, con miras a verificar y hacer más fiables los ejercicios para el fortalecimiento de la memoria colectiva en jóvenes del pueblo de los Pastos. A continuación, se hace referencia a cuatro fases que corresponden con los objetivos planteados.

La Seducción del Teatro-Danza. La primera fase fue trabajada durante 3 meses ( 9 semanas) y un total de 48 horas; contempló 15 talleres exploratorios orientados hacia el fomento del arte en un escenario rural, pues "el arte de la memoria conserva su teatro como un lugar donde el hombre puede acordarse de su destino y agradecer su vida" (Monsalve, 1995, p. 43). Se evidenció el avance en el reconocimiento de su cuerpo, se detectaron algunas deformaciones históricas y el descubrimiento de talentos; paulatinamente empezaron a sentirse personas activas en la historia del Pueblo Indígena de los Pastos. Reconocieron su territorio como escenario político, frente a dinámicas contemporáneas que arrasan con lo propio de los pueblos. Los ejercicios lograron grabar en su mente datos que iban recolectando de la comunidad para su posterior representación, pues esta propuesta corresponde al teatro de la memoria, que al igual que la propuesta de Monsalve (1995), pretende levantar un mapa simbólico del teatro en los territorios para "dibujar en él las lagunas, las rocas y los árboles donde los hombres han celebrado los rituales, matrices de las artes. Queremos seguir el curso del desarrollo de tradiciones escénicas y de las circunstancias de su florecimiento” (p. 11).

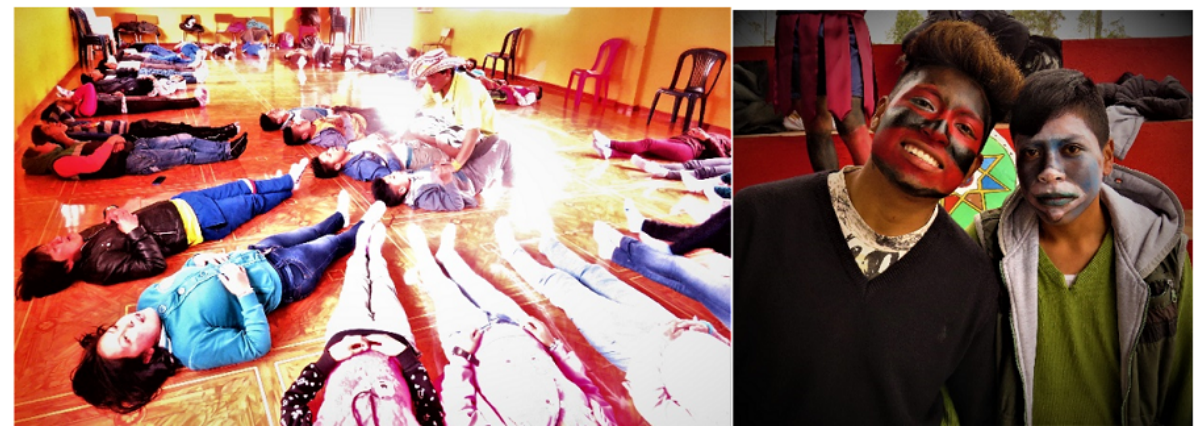

FIGURAS 4 Y 5

Grupo de Teatro Para la Memoria. Taller de respiración y de maquillaje.

Fuente: Archivo personal del equipo investigador, Cumbal, Nariño, Colombia, Junio 2016

$\mathrm{Al}$ empezar cada taller se proponían juegos teatrales para mejorar habilidades, aumentar la confianza y sentires entre las personas jóvenes, inicialmente reconocieron su cuerpo y elevaron su autoestima (Figuras 4 y 5); las capacidades que iban encontrando en sus corporalidades les permitían reconocerse y visionarse como seres talentosos, capaces de crear lo inexistente. "Los ejercicios en los talleres permitieron elevar la autoestima, aceptar tal cual somos, a respetar nuestro cuerpo y el de nuestros compañeros" (Canacuan, comunicación personal, 10 de noviembre, 2016). De esta misma manera fueron respetando el cuerpo del otro, aumentando las confianzas y expresiones fraternales entre el grupo, ya no limitaban su visión en el morbo, sino que trascendía el sentir colectivo entre el tejido de ideas, experiencias y rumbos de vida.

La manera directa de liberar los cuerpos es a través de la experiencia, que dimensiona "la interacción del organismo con su ambiente humano, así como físico, que incluye los materiales de la tradición, instituciones y circunstancias locales" (Dewey, 2008, p. 278). Las sensaciones, deseos y conocimientos son fragmentos que expresa el cuerpo desde la experiencia en su transitar, así dimensiona la mente y conciencia para lograr estados psicológicos en un ambiente natural que inicialmente es imitativo, pero "cuando el vínculo del yo con su mundo se rompe, entonces también las diversas maneras como el yo interaccionan con el mundo dejan de tener una conexión imitaria entre sí” (Dewey, 2008, p. 279). Los patrones corporales rompieron la rutina impuesta por una apropiación asumida, pues es preciso experimentar cada sensación y deseo para formar pretensiones de vida, tomar posturas y aflorar en el mundo. 
El explorar posturas con su cuerpo les exigía mayor potencial artístico, por ello fueron más conscientes sobre posiciones al caminar, actuar y expresar. A nivel sensorial, los sentidos jugaron un papel fundamental en la preparación para las actividades centrales del taller, por ello se trabajaba desde el tacto, el oído, la vista, el olfato. Para ampliar la concepción de estéticas propias se indagaron propuestas escénicas de diversas culturas, reconociendo que "no podemos ser únicamente consumidores de obras ajenas porque ellas nos traen sus pensamientos, no los nuestros. Pueden enriquecernos; pero más ricos seremos produciendo, nosotros también, nuestro arte, y estableciendo, así, el diálogo" (Boal, 2009, p. 173).

La imitación fue importante en el proceso inicial, se apropiaron de personajes, de su cultura, creando posturas, voces y reflexiones sobre cada uno, así, al ser y estar en la posición de otro, fue evidente el crecimiento de un sentir más humanizado y consciente de jóvenes Pastos, quienes moldeaban su estilo y postura para mostrar lo propio. "La estética no es la ciencia de lo bello, como se suele decir, sino la ciencia de la comunicación sensorial y de la sensibilidad. Es la organización sensible del caos en el que vivimos" (Boal, 2009, p. 43).

Los encuentros entre los meses de abril y junio del 2016, permitieron que las personas asistentes reconocieran su cuerpo y tuvieran una lectura crítica de dinámicas colonizadoras. En el arte, hallaban una puerta para direccionar su vida, para pasar su tiempo libre aprendiendo y así, atreverse a negar el sometimiento juvenil entre trabajos forzados, vicios y actividades de personas mayores; de esta forma, se creaba un nuevo espacio juvenil para la formación socio-cultural en la vereda, un aprendizaje más significativo que comprendía la práctica en contexto, vivencial, experimental, para que los estudiantes llevaran sus aprendizajes a la realidad en el funcionamiento de entornos sociales, pues "para que las personas alcancen y mantengan una forma de vida democrática, han de tener oportunidades de aprender lo que esta forma de vida significa y cómo se puede practicar en concreto" (Meza, 2013, p.75). Esto permite un posicionamiento crítico frente a realidades y el empoderamiento como actores para transformar. Con su participación sentaron una posición política en escena y renombraron la historia en ritmos colectivos.

Los talleres permitieron el reconocimiento del otro, que significó un sentir colectivo y espiritual. Todo estuvo enmarcado en los cuatro momentos referidos por Boal (1980) para el arte de la interpretación. conocer el cuerpo, desarrollar la capacidad expresiva, crear formas sencillas para representar realidades y dejar de ser persona espectadora para actuar.

Guion de la obra de teatro del grupo "Danzantes de Pensamientos": El retorno de las perdices. En esta fase se imparten 13 talleres, durante 3 meses ( 8 semanas) y un total de 44 horas, se procedió a construir un montaje escénico desde la Antropología Teatral ${ }^{[18]}$ como resultado del proceso de los talleres exploratorios. Juan Monsalve en su estudio El baile del muñeco (1995) profundiza en rituales celebrados en la Amazonia Colombiana, dejando entrever algunas manifestaciones espirituales que encarnan las cosmovisiones de los pueblos indígenas. El teatro-danza es la herramienta para crear actos performáticos que transmiten sabiduría ancestral, en este caso se logró el impacto, al evidenciar en las personas jóvenes la apropiación de saberes, historia y un gran entusiasmo por multiplicarlos; se transmitieron manifestaciones míticas, ritualísticas y de cosmovisión, para el ser-estar indígena.

Cada escena construida -en total cuatro-, posibilitó la escritura de un guion escénico y la consolidación de una obra de Teatro-Danza desde estéticas propias, enmarcadas en el enfoque crítico social que "no tiene un interés meramente especulativo, simplemente de describir lo que hay ahí, sino de proporcionar las armas teóricas para romper esas cadenas que ha mostrado que existen" (Vasco, 1994, p. 23). Los churos cósmicos, el sol de los Pastos, el volcán Cumbal y algunas figuras míticas como la luna o el "curandero", fueron resaltados en los cuerpos y rostros, con el fin de evidenciar la simbología de su pueblo indígena ${ }^{[19]}$ y reconocer su pensamiento. Los vestuarios fueron diseñados por ellos, dependiendo de la escena; algunos eran coloridos para representar la diversidad en Latinoamérica y los procesos interculturales, mientras otros se notaban uniformes, debido a la intención de resaltar lo conservado en cada etnia. "La comunidad indígena Cumbal, utiliza la danza en sus rituales y expresa a través de ella sus creencias, costumbres y demás sensaciones siendo 
de mayor importancia La Danza de las Perdices, la cual hace parte de su propia riqueza cultural" (Gustin, Insuasty y Benavides, 2007, p. 12). Por ello se plasmó su historia en movimientos colectivos que remembran las raíces identitarias como pueblo indígena que mantiene su organización y defiende sus costumbres.

Se crearon 78 personajes con intencionalidades concretas: una perdiz negra con sus cinco guardianes (Figura 6) y una perdiz blanca con sus cinco guerreros, que representaron el mito de creación en torno a la lucha por la ocupación y la población del territorio de los Pastos. Un abuelo que narra la historia y evidencia la importancia de la transmisión oral. Diez danzantes de Toba, ritmo andino de origen boliviano que refleja furia, actitud de guerra y defensa ancestral. Dos reyes españoles que llegan al Abya Yala con el fin de colonizar, con ellos diez africanas atadas y condenadas en la eterna esclavitud, que encarnan los procesos interculturales de la región. Diez danzantes de Tinku, ritmo andino que refleja el encuentro entre pueblos y la reconciliación en los territorios. Dos espíritus que imitan energías, poderes sobrenaturales y espiritualidades presentes en territorios ancestrales. Una escena representó algunas prácticas culturales actuales, con la figura del gobernador, 9 cabildantes y 20 personas de la comunidad en general, quienes usan lana, chicha, cuyes, chapil ${ }^{[20]}$,bastones de mando, leche, vasijas de barro, ruanas de ovejo y otros elementos característicos de su cultura. Finalmente, como se visualiza en la Figura 7, un chamán -personaje principal-, que siempre está en escena curando, reconfortando, retando, celebrando y convocando fuerzas.

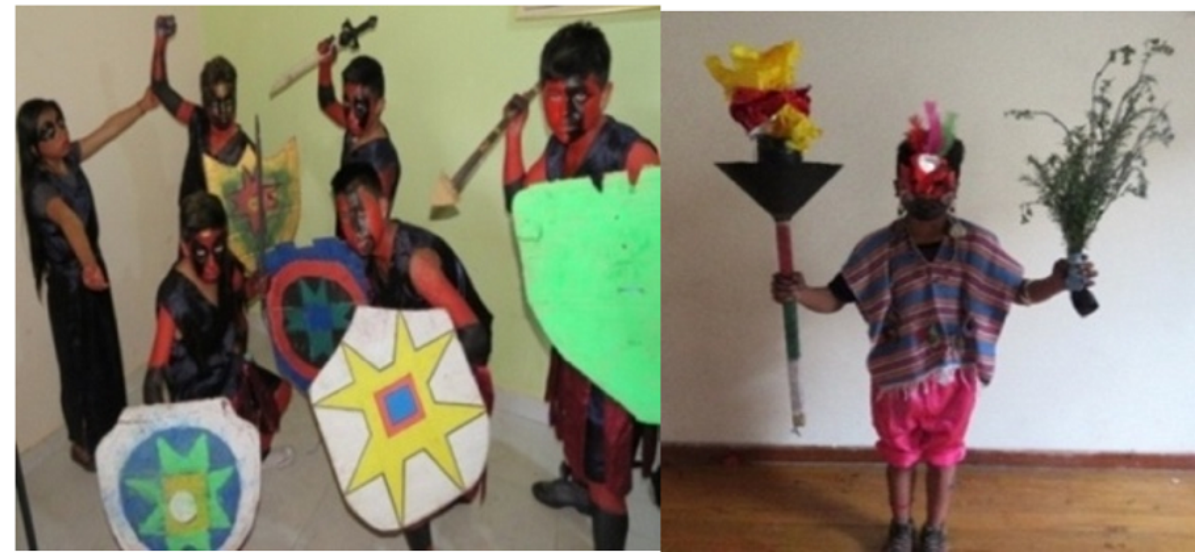

FIGURAS 6 Y 7

Grupo de Teatro Para la Memoria. Perdiz Negra con cinco guerreros y Chamán Fuente: Archivo personal del equipo investigador, Cumbal, Nariño, Colombia, Octubre 2016

Cada personaje se creó con cualidades físicas y emocionales según las indagaciones realizadas, teniendo en cuenta las afinidades con cada participante. Por ejemplo, el Chaman: representa un sabedor curandero, brujo y médico tradicional; tiene grandes saberes medicinales para curar enfermedades físicas, mentales y espirituales; él está presente en todas las escenas y siempre ha acompañado procesos de resistencia. Las plantas sagradas y el fuego encendido lo acompañan, son sus armas, convoca diferentes energías a quienes obedece porque lo iluminan, le dan sabiduría y poder. Según Ortiz (2011), desde tiempos milenarios las comunidades indígenas colombianas han utilizado sus formas propias de curación física y espiritual, "esta tradición es apoyada en conocimientos profundos de la madre tierra y sus frutos, nace del respeto y convivencia con la naturaleza" (p. 30)

Su vestuario: pantalón rosado, ruana de colores, un pebetero con la llama encendida y antifaz, lleva plantas en sus manos, aretes y collares de semillas prendidas a su cuerpo; su cara y extremidades están pintadas con simbología de su pueblo. De esta manera se fueron construyendo las escenas e identificando momentos emblemáticos de la historia de los pueblos indígenas: 1. Mitología propia, 2. Llegada de los colonizadores, 3. Rituales desde el sentir espiritual, 4. Fiestas populares y prácticas culturales que se han mantenido.

Rememorando la historia de los Pastos. Al tener consolidado el montaje escénico, se recibieron propuestas para mostrar la creación colectiva. A nivel municipal, la presentación inauguró el Inti Raymi ${ }^{\text {[21] }}$ 
Cumbal 2016 (Figura 8), la más importante celebración en la comunidad indígena, puesto que simboliza el nacimiento de un nuevo año en la visión del mundo andino. Asimismo, se acompañaron eventos de las instituciones educativas de Cumbe, Llorente, Sagrado Corazón de Jesús en Cumbal (Figura 9) y se promovió la integración para impulsar espacios de formación artística para jóvenes. A nivel departamental se participó en el "Festival Liceísta", en el emblemático escenario de la ciudad de San Juan de Pasto: el Teatro Imperial como invitados especiales del Liceo de la Universidad de Nariño. ${ }^{[22]}$ A nivel nacional, la Universidad del Valle los invitó a participar en la celebración anual del Cabildo Indígena: Taitas, Memorias, Tulpasy Kasrhak (Figura 10), reconocido por su impacto artístico, académico, social y comunitario; lo más relevante de la experiencia en esta fase, es que compartieron su trabajo con otros grupos de artistas que promueven el saber y la creación ancestral. Los recursos fueron gestionados en eventos organizados por la comunidad, que apoyaron la nueva generación de líderes en el territorio y su iniciativa performática.

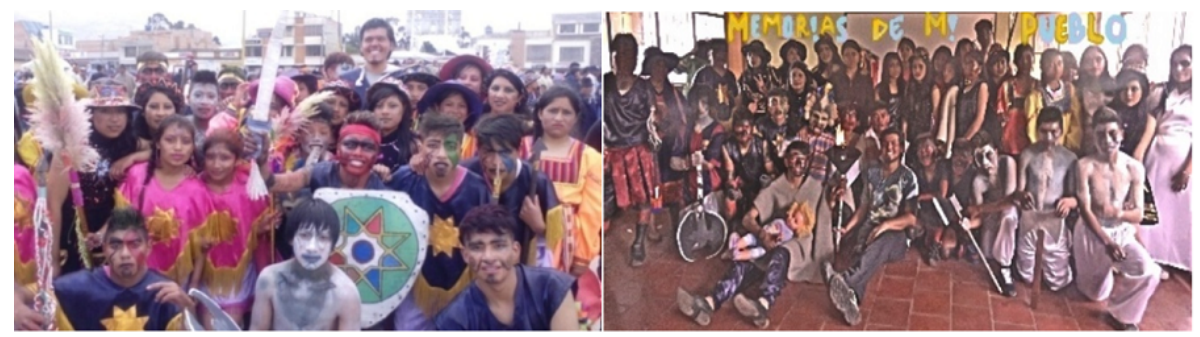

FIGURAS 8 Y 9

Grupo de teatro Danzantes de pensamientos, participación en Inti Raymi, fiesta del sol, Junio de 2016, Cumbal, Nariño, Colombia. Fuente: Archivo personal del equipo investigador, Universidad del Valle, Cali, Colombia, 2016

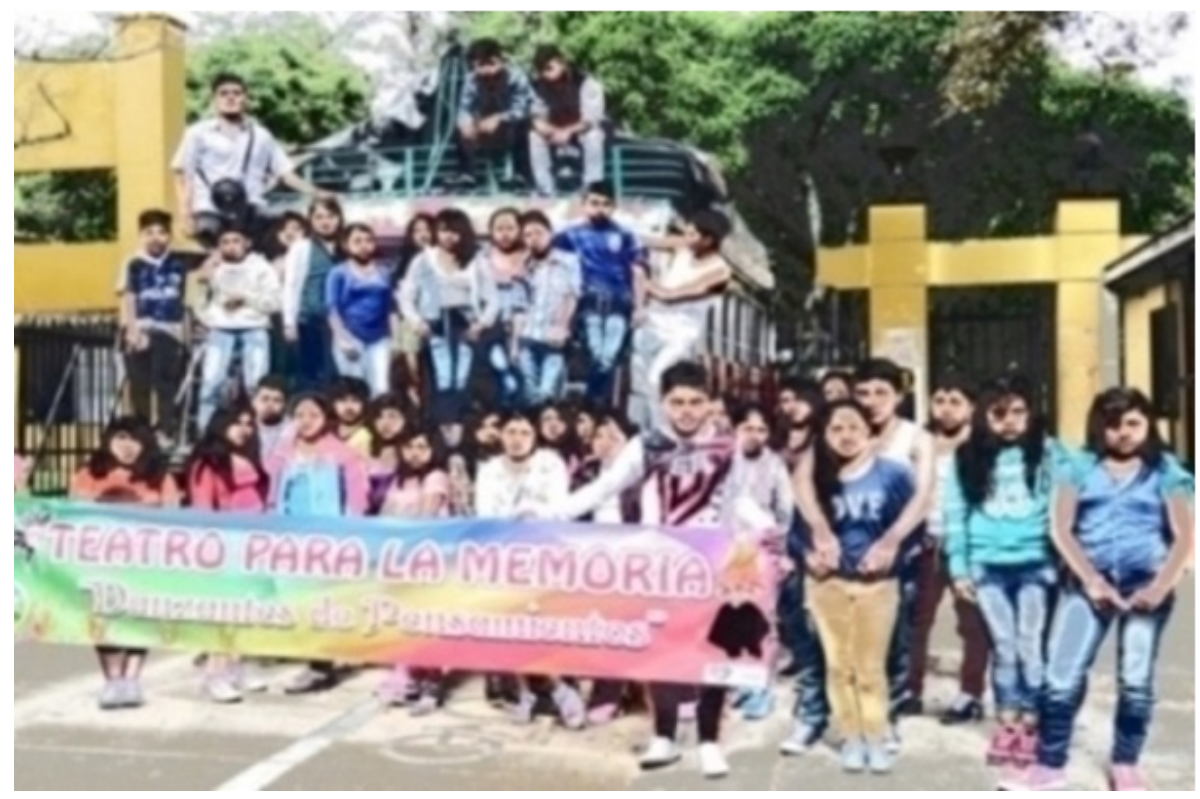

FIGURA 10

Participación en el I Encuentro de música y danza folclórica, tradicional y autóctona por la paz. Fuente: Archivo personal del equipo investigador, Universidad del Valle, Cali, Colombia, 2016

$\mathrm{Al}$ joven grupo de Cumbal, la dimensión espacial lo transformó en viajero, la mayoría de sus integrantes no había viajado nunca a lugares más lejanos que Ipiales ( 2 horas de distancia). Esto alimentó el enfoque crítico-social, desde sus raíces promovieron una verdadera comunicación liberadora ${ }^{[23]}$. El viaje fortaleció las relaciones, permitió diversas formas de hospitalidad, y acrecentó su responsabilidad de sujetos activos en la historia. La pedagogía del viaje revitaliza al enfrentarse a diversas situaciones fuera de las comodidades de un 
hogar tradicional; surge un sentir colectivo más constante y profundo. Razón tenía Polar (2003), al referirse al Sujeto Migrante, que cada viaje alimenta la construcción de mundo y se plasma en Testimonios ${ }^{[24]}$.

Mingando se construye colectividad. Las mingas son un espacio que materializa el sentir comunitario; las personas se unen para un bien común, puede ser para construir una casa, cosechar papa, arreglar los caminos, entre otros propósitos; en este caso, con las mingas de pensamiento se fortaleció la memoria cultural y colectiva para el devenir histórico de los pueblos a través del diálogo de saberes y el trabajo comunitario; por ello, se consideró una estrategia de trabajo etnográfico adecuada. En total se desarrollaron cinco que permitieron sistematizar y evaluar el impacto del proyecto en la comunidad, en todas se dimensionó el poder creador que constituye consolidar un grupo de teatro y danzas; participaron padres y madres de familia, personas investigadoras, estudiantes y vecinas del sector. La Tabla 1 indica la matriz de categorías inductivas trabajadas en las mingas teniendo en cuenta Memoria Colectiva, Teatro y Danza.

Para potenciar los procesos de oralidad y transmisión de saberes, las personas participantes indagaron continuamente a las mayores, así se fue consolidando la memoria ancestral, heredando la palabra y tejiendo trozos de hechos históricos. Para Pacheco (2016), la oralidad no puede concebirse como "el predominio de una modalidad comunicacional, tampoco, en términos negativos, como privación o uso restringido de la escritura ni, finalmente, como una suerte de subdesarrollo técnico o atraso cultural, sino como una auténtica economía cultural, relativamente autónoma" (p. 54). La escritura convertida en danza teatro recrea de otra forma, expresa un gran poder de resistencia. Recuperar la oralidad, la creatividad, el registro visual de los pueblos, implica trascender códigos culturales predominantes, a favor de la subjetividad andina; esta es una forma de sembrar paz, contribuir al sentido de pertenencia con el territorio y a su empoderamiento social.

En efecto, la educación en cultura de paz empodera individuos y colectivos para asumir la transformación pacífica de conflictos, por ello es viable mostrar escenarios que promueven miradas incluyentes sobre posibilidades humanas para existir. Es tan grande la capacidad de creación del ser humano, que logra transformar cuerpos y conciencias sólo con un movimiento o una palabra; por ello, cada vez que se produce un acto comunicativo, éste tiene un peso simbólico en el crecimiento del otro, de sí mismo.

La Comunicación No Violenta es un modo de pensar y de hablar que aspira a fomentar la comprensión y el respeto mutuo en las relaciones. Ayuda a la persona a vincularse con la parte de sí misma capaz de comprender con el corazón y de expresarse sin agresiones verbales. Cuando intentamos vivir y aplicar este modo de relacionarnos, no sólo nos preocupamos de lo que está ocurriendo, sino también de lo que cada uno experimenta. Esto permite abordar a los demás teniendo siempre presente que son seres humanos como nosotros y, de esta manera, estimulamos nuestra propia bondad y la del otro (Stappen, 2019, p. 04).

En el contexto colombiano se están construyendo bases para afianzar la paz como necesidad concreta y anhelo de los pueblos; por esta razón, los proyectos educativos sirven como garantes en el cimento de un nuevo país, donde se priorice la democracia, la vida, la justicia y la libertad de pensamiento. Es necesario que se transformen los sistemas educativos que solo guían a la persona joven desde la historia oficial, que llevan al ocultamiento y al olvido de las raíces, intentando imponer la idea de un mundo ancestral falso e inferior a otro superior y real que viene de afuera.

Comprendiendo los procesos interculturales actuales, las escuelas deben reevaluar sus currículos, que integren conocimientos desde la diversidad cultural y amplíen miradas con sus semejantes. "Educar para la paz y para la democracia, implica la construcción del diálogo favorable a la posibilidad de que el sujeto dé cabida a la escucha del otro y con ello, que en su propio mundo conceda un espacio al semejante" (Ceballos, 2013. p.45). En este aspecto, toda propuesta educativa necesita ampliar su visión para integrar la diversidad en interacción, que "respete ante todo el ser, que propicie la conciencia de sí, la inserción crítica e histórica de los sujetos a través del diálogo horizontal, libre y de la acción solidaria en la transformación de sus condiciones de existencia" (Ovelar, 2005, p. 5). 


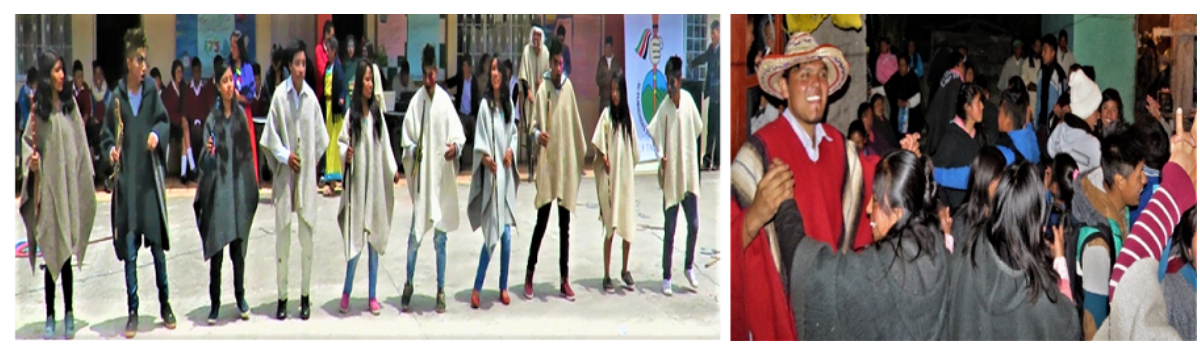

FIGURAS 11 Y 12

Grupo de teatro Danzantes de pensamientos, mingas comunitarias, Octubre de 2016, Cumbal, Nariño, Colombia ${ }^{[25]}$

Fuente: Archivo personal del equipo investigador.

El teatro promueve la integración de los pueblos (Figuras 11 y 12) y la expresión de diversas posturas, ya que uúnicamente a favor del diálogo, de la creatividad, y de la libertad de producción y transmisión del arte (...), será posible la liberación consiente y solidaria de los oprimidos” (Boal, 2009, p. 26). El Teatro del Oprimido contribuye a salvaguardar la cultura y a remembrar acontecimientos fundamentales de los Pastos, fortalece procesos organizativos de cualquier pueblo y propende por un territorio libre de guerra, lleno de memoria, identidad y convivencia armoniosa. La vida es un baile de diversos ritmos, al bailar se curan molestias espirituales, el cuerpo se inspira y explora, la danza es parte fundamental en las culturas, con ella se conmemoran rituales, fiestas propias y se consolidan lazos fraternos. Los ritmos andinos identifican al suroccidente colombiano, mantienen un legado ancestral desde sus tradiciones, cosmovisiones y espiritualidad indígena, esta es su forma de resistir al colonialismo promovido por hegemonías occidentales, "el universo sonoro de los Andes se libera de viejas y erróneas etiquetas y es asumido como lo que es, un inmenso mosaico de latidos y retumbos, ecos y trinos, rasgueos y punteos a lo largo de la cordillera” (Hernández, 2008, p. 14). 
TABLA 1

Matriz de Categorías y sistematización de actividades

\begin{tabular}{|c|c|c|c|c|c|}
\hline \multicolumn{6}{|c|}{$\begin{array}{l}\text { Objetivo: Sistematizar la experiencia educativa, a través de mingas de pensamiento que } \\
\text { permitan evaluar el impacto en la comunidad. }\end{array}$} \\
\hline $\begin{array}{l}\text { Categorías } \\
\text { Inductivas }\end{array}$ & $\begin{array}{l}1 \text { Minga de } \\
\text { Pensamiento7 } \\
\text { Abril } 2016\end{array}$ & $\begin{array}{l}2 \text { Minga de } \\
\text { Pensamiento } 1 \\
\text { Junio } 2016\end{array}$ & $\begin{array}{l}3 \text { Minga de } \\
\text { Pensamiento } 25 \\
\text { Agosto } 2016\end{array}$ & $\begin{array}{l}4 \text { Minga de } \\
\text { Pensamiento } 29 \\
\text { Octubre } 2016\end{array}$ & $\begin{array}{l}5 \text { Minga de } \\
\text { Pensamiento } 10 \\
\text { Noviemb. } \\
2016 \\
\end{array}$ \\
\hline \multicolumn{6}{|c|}{ Memoria Colectiva } \\
\hline \multicolumn{6}{|c|}{$\begin{array}{l}\text { Diálogos con } \\
\text { mayores y } \\
\text { sabedores }\end{array}$} \\
\hline $\begin{array}{l}\text { Reproducción } \\
\text { de } \\
\text { conocimientos } \\
\text { propios }\end{array}$ & & & & & \\
\hline \multicolumn{6}{|l|}{$\begin{array}{l}\text { Participación } \\
\text { activa }\end{array}$} \\
\hline \multicolumn{6}{|l|}{$\begin{array}{l}\text { Sentido de } \\
\text { pertenencia }\end{array}$} \\
\hline \multicolumn{6}{|l|}{$\begin{array}{l}\text { Conciencia } \\
\text { social }\end{array}$} \\
\hline \multicolumn{6}{|l|}{ Teatro } \\
\hline \multicolumn{6}{|l|}{$\begin{array}{l}\text { Socialización } \\
\text { de ideas }\end{array}$} \\
\hline \multicolumn{6}{|l|}{$\begin{array}{l}\text { Conciencia } \\
\text { política }\end{array}$} \\
\hline \multicolumn{6}{|l|}{$\begin{array}{l}\text { Reflexión } \\
\text { sobre escenas }\end{array}$} \\
\hline \multicolumn{6}{|l|}{ Danza } \\
\hline \multicolumn{6}{|l|}{$\begin{array}{l}\text { Lectura de } \\
\text { dinámicas } \\
\text { colonizadoras } \\
\end{array}$} \\
\hline \multicolumn{6}{|l|}{$\begin{array}{l}\text { Gusto por } \\
\text { ritmos } \\
\text { andinos } \\
\end{array}$} \\
\hline $\begin{array}{l}\text { Compartir } \\
\text { alimentos }\end{array}$ & & & & & \\
\hline
\end{tabular}

Fuente: Elaboración propia.

Para el pensamiento indígena, todo en la vida es una danza, el mismo universo es ritmo, giro, atracción y reacción, la acción personal está unida a la Madre Tierra; con la melodía del cuerpo se manifiestan sufrimientos, esperanzas y deseos de libertad.

Al final de este proceso de creación colectiva se construyó una Cartilla Didáctica El Teatro Danza, que reúne un debate pedagógico-epistemológico en relación con el arte y los métodos de enseñanza actual, es un ejemplo de dignidad raizal, para seguir fortaleciendo el pensamiento crítico y la memoria colectiva de las personas jóvenes.

\section{DiSCUSIÓN Y CONCLUSIONES}

La necesidad de abrir escenarios artísticos en zonas fronterizas, donde el abandono estatal, la presencia grupos $\operatorname{armados}^{[26]}$, cultivos ilícitos y otros problemas estructurales arremeten contra la dignidad en la vida juvenil, hace que cobre mayor relevancia esta investigación, ya que posibilitó la construcción de consciencias y el empoderamiento popular, en la transformación de espacios políticos de paz. Los talleres contribuyeron a que las personas jóvenes no se consumieran en rutina de mayores, ni en redes sociales, aprendieron a respetar 
el cuerpo de los demás y el suyo, elevando su autoestima; además, el hecho de viajar a otras ciudades y escenarios, amplió sus perspectivas de vida, compartieron tarimas con artistas nacionales e internacionales, entretejieron saberes con otros pueblos y conocieron la universidad pública, a la cual muchos se inscribieron y algunos lograron ingresar. El teatro en zonas rurales, permitió construir estéticas juveniles populares desde la identidad cultural.

Este tipo de estudios debe desarrollarse en cada territorio con desafíos en ciencia y educación propia. La etnoliteratura es una forma de cultivar la memoria, proteger los saberes autóctonos y autónomos, propiciar conversaciones sobre identidad y construcción de paz, de recuperar una visión vitalizadora de lo que es Latinoamérica; permite la libertad de expresión del incalculable valor de la diversidad. El posicionamiento de estéticas propias de los llamados subalternos, posibilita el encuentro de expresiones étnicas, que mantienen viva la cultura de los pueblos con sus particulares escrituras y lecturas; habla el cuerpo, los sentires y placeres en geografías singulares.

Las comunidades ancestrales están llenas de tesoros, secretos, curaciones y misticismos que desvelan verdades protegidas. Desde el teatro contemporáneo es posible reconstruir la identidad ancestral de los pueblos originarios como los Cumbales; gracias al arte se fomenta el valor de la comunidad y se recontextualiza su imaginario simbólico. De esta manera se libera el colonialismo reproducido desde siglos, se fortalece como lo sostendrían Freire (2005) y Boal (2009), la liberación de la opresión, y se reconoce e incluye el valor de la diferencia.

La literatura trasciende su denominación convencional, más allá de lo alfabético se habla con el cuerpo, con la voz que nace en escena, sin grafocentrismo, sin prácticas de dominación; la danza teatro reconstruyó críticamente el contexto, ayudó a descolonizar, a reconocer y valorar la diferencia, a fluir desde una oralidad corporal e interpretar la alteridad con una mirada más amplia y reconciliada. Plantea nuevos retos epistemológicos que no excluyen, marginan o reducen el valor oral de la cultura, "lleva a la revisión de muchos conceptos establecidos en la práctica de la teoría, la historia y la crítica literarias y, más aún, en la práctica de los estudios culturales" (Pacheco, 2016, p. 224).

La concepción artística de pueblos indígenas, como los Pastos, se caracteriza por una visión trascendental de la vida, en el teatro aflora el mito, la danza, la música, la lucha por la dignidad; se expresa unidad porque la escritura no se reduce a las palabras, la creación viene de una memoria colectiva en donde habla la naturaleza y lo sagrado. En esta medida todo el universo es escritura y en el teatro, toma relevancia lo que comunica el cuerpo, la palabra se corporaliza.

Esta investigación reconoce la oralidad que jóvenes cumbales tradujeron en la obra como El retorno de las perdices, que significa el retorno a sus raíces, por eso contó con la participación de la comunidad; la obra representó su pasado, su presente y también su devenir. Se produjo así un impacto cultural, social y educativo positivo, incluir su riqueza ancestral en la representación reafirmó su contexto y su lugar en el mundo.

Esta investigación fomenta el pensamiento y el lenguaje crítico, las palabras se convierten en identidades colectivas, experiencias subjetivas de lo esencial. Se trasciende la representación dominante, se deconstruye la convencionalidad excluyente a favor de manifestaciones artísticas que liberan del logocentrismo, porque, como lo señala Derrida (1989), el concepto de escena propuesto por Artaud, desenmascara la falsedad de la sociedad: "La teatralidad tiene que atravesar y restaurar de parte a parte la existencia y la carne" (p. 38).

Gracias a la estrategia pedagógica del teatro-danza, fue posible trabajar desde el contexto para recuperar y resignificar la memoria. Se logró que las personas jóvenes fueran creadoras, no sólo afirmaron las tesis de Boal, la de conocer su corporalidad, expresión y realidad a través de su particular autoría, sino que además, logran lo que Corazza (2013) propone: desarrollar una didáctica creativa, capaz de traducir su pensamiento; la interpretación de lo que son se lleva a escena, su obra Teatropara la memoria dignifica el pueblo de los Pastos y es un llamado a la renovación de la educación desde una literatura viva, nacida de la propia comunidad.

El teatro permite la expresión de una multiplicidad discursiva, donde no predomina el dominio de unos sobre otros, -según Foucault (1992), el dominio caracteriza la cultura occidental- sino la creación, que en 
el caso de los Pastos es absolutamente vitalista, a pesar de los problemas de exclusión económica y política que han padecido, comprendieron que es posible recuperar su memoria y su historia de una manera alegre y colectiva. Las mingas de pensamiento aportaron pertencia, participación, diversidad, el teatro se convirtió en la obra de todas las personas, y fue un motivo para celebrar lo que son y lo que es su entorno natural.

Hay que seguir descubriendo a través del teatro-danza la oralidad en movimiento, continuar la reflexión de las ideologías dominantes, y como lo sugiere Pacheco (2016), revisar y valorar el componente popular y ficcional, para desvelar los diferentes sonidos de la memoria. El Teatro del Oprimido sigue vigente, así lo demuestran estudios como los de Motos y Navarro (2011), Puga (2012), Chesney-Lawrence (2013), Moliner, Francisco y Cabedo (2014) y, Calvo, Haya y Ceballos (2015) que promueven la reflexión crítica sobre la realidad desde la experiencia comunitaria, y facilitan el debate entre la educación y los problemas culturales. El teatro promueve la equidad, el respeto por la diferencia y la paz, condiciones necesarias para una sana convivencia que también requiere, educar a las personas educadoras para lograr una educación menos bancaria.

Los Pastos a través del teatro visibilizaron su singular cosmovisión ecopoética, los simbólicos guerreros protejen los bosques, las aguas, la cosecha. La naturaleza se respeta, es concebida como la madre; tierra y sol son la fuente primordial que permite la vida, el amor, la luz y el crecimiento material y espiritual. El sol estrellado que los identifica expande sus puntas a todo el universo. Desde su autonomía, conectaron con lo universal, porque la vida de los Cumbales, así como sucede en el pueblo Náhuatl, es una forma de sagrada celebración.

El teatro-danza dejó en las personas jóvenes participantes una semilla de vida, las conquistó, ahora las encamina por el fortalecimiento de procesos de resistencia en el territorio. Una fisura artística fue abierta en un mundo que niega al otro, que saquea y consume; se dio la oportunidad de materializar posturas colectivas con el orgullo del ser indígena. Los planteamientos de Freire (1970) se revitalizan porque se cambiaron las relaciones de enseñanza-aprendizaje desde el diálogo de saberes y el criticismo; afloró un mundo nuevo: seres humanos solidarios con capacidad creadora.

La antropología teatral atrajo las juventudes que revelaron el espíritu del cóndor, del jaguar, del águila, del quetzal. Provienen de un pueblo invadido de influencias exteriores y crearon arte como herramienta para resistir a los bombardeos sistemáticos del capital, dando fuerza a procesos de educación propia y resistencia cultural. "Agradezco por promover el arte en esta vereda, fue una muy bonita labor. Jamás pensé que todos pudiéramos cumplir tantos sueños, (...) Todo lo que pasó en este grupo, cambió mi vida para siempre”. (Cuastumal, comunicación personal, 10 de noviembre, 2016). El teatro muestra que sus planteamientos son válidos para cualquier temática que responda a la emancipación de los pueblos, en un escenario popular y en nuevas generaciones.

El montaje escénico demostró que las propuestas artísticas motivan a jóvenes a descubrir sus legados originarios, a reconocerse como nativos y accionar en favor de la abundante riqueza sapiencial, espiritual y material. Volver a la tierra, a lo que son, a sus saberes, ser la respuesta ante la soledad y el olvido, porque muchos cumbales se marcharon a tierras hostiles, a trabajar en cultivos ilícitos o mendigar en las ciudades capitales. "Es para estas situaciones que nos debemos preparar como pueblos, pues el que las personas jóvenes salgan de nuestro territorio sin la firme convicción de quienes somos, puede ser suicida para la cultura (...)" (Estrada, 2007, p. 2). Este estudio legitima el Teatro para la Memoria (Camelo y Chirán, 2016) al crear y divulgar estéticas no convencionales. "Es la organización sensible del caos en el que vivimos solitarios y gregarios, intentando construir una sociedad menos antropofágica” (Boal, 2004, p. 43). El teatro generó principios éticos-políticos abrió escenarios artísticos de transformación social, ayudó a comprender la importancia del tejido cósmico. 


\section{REFERENCIAS BIBLIOGRÁFICAS}

Adame, D. (2006). Teatralidad india y comunitaria en México: un acercamiento desde la complejidad. América sin Nombre, (8), 18-26. doi: https://dx.doi.org/10.14198/AMESN2006.8.03

Aguayo, F y Roca, L. (2002, Octubre). Estudio introductorio: imágenes e investigación social. En Primer Congreso Internacional sobre Archivos Sonoros y Visuales en Latinoamérica. Ciudad de México, México. Recuperado de ht tp://durito.nongnu.org/docs/Aguayo_Roca_2.html\#sdfootnote1sym

Alcaldía Municipal de Cumbal. (2016) Plan de Desarrollo Municipal. Cumbal - Colombia: Consejo Territorial de planeación.

Araiza, E. (2009, Diciembre). ¡Eso no es teatro! ... Además, así no son los indígenas. Notas acerca del relativismo en la interpretación de las artes de la escena. Relaciones. Estudios ded historia y sociedad. 30(120), 99-137. Recuperado de http://www.scielo.org.mx/scielo.php?script=sci_arttext\&pid=S0185-39292009000400004

Artaud, A. (1978). Segundo Manifiesto del Teatro de la Crueldad. Akal, 6, 199-208.

Boal, A. (1974). Técnicas Latinoamericanas de Teatro Popular: Una revolución copernicana al revés. Argentina: Ediciones Corregidor.

Boal, A. (1980). Teatro del Oprimido 1: Teoría y Práctica. México: Nueva Imagen.

Boal, A. (2004). Organización internacional teatro del oprimido ITO. Recuperado de https://layapacultural.wordpres s.com/2010/04/13/organizacion-internacional-del-teatro-del-oprimido-declaracion-de-principios/

Boal, A. (2009). La estética del oprimido. España: Artes Escénicas.

Bonfil, G. (1991). Pensar Nuestra Cultura. México: Editorial Patria, S. A.

Brecht, B. (1972). La politica en el teatro. Buenos Aires - Argentina: Alfa Argentina.

Calvo, A.; Haya, I. y Ceballos, N. (2015) El Teatro Foro como estrategia pedagógica promotora de la justicia socia. Revista Interuniversitaria de Formación del Profesorado, 29(1), 89-107. Recuperado de http://www.redalyc.org /pdf/274/27439665007.pdf

Ceballos, P. (2013). Educación para la paz y la democracia. Revista RAXIMHAI, 9(1), 35-48.

Camelo, M. y Chirán, E. (2016) Teatro para la memoria: Danzantes de pensamientos (Tesis de maestría sin publicar). Universidad de Nariño, Colombia.

Campion, M. (2015), Entre la memoria histórica y el atentado: las relaciones transfronterizas de los indígenas Pastos del Nudo de Waka. Revista Cientifica Géneral José Maria Córdova, 13(16), 243-262. Recuperado de http://ww w.scielo.org.co/pdf/recig/v13n16/v13n16a12.pdf

Carrión, C. (2015). Desafiando al Estado-nación: Reclamos de autonomía del pueblo Pasto. Universitas Humanistica, (80), 133-157. Recuperado de https://doi.org/10.11144/Javeriana.UH80.denr

Cassany, D. (2008) Literacidad Critica: leer y escribir la ideología. Barcelona: U. Pompeu Fabra.

Chesney-Lawrence, L. (2013). Las teorías dramáticas de Augusto Boal. Revista de Estudios Culturales. A Journal of Cultural Studies, 26, 25-55. Recuperado de http://digitalcommons.conncoll.edu/teatro/vol26/iss26/3/

Chirán J., y Puenguenan A. (2015). Tejiendo pensamientos para dinamizar los saberes propios de los Cumbales (Tesis de Maestría). Universidad de Manizales, San Juan de Pasto, Colombia.

Corazza, S. M. (2013). Didáctica-artista da tradução: transcriações. CAPES-INEP 6,(01), 185-200. Recuperado de h ttps://bit.ly/34RCs99

Daza Cuartas, S. (2009). Investigación - Creación, un acercamiento a la investigación en las artes. Colombia: Iberoamericana Institución Universitaria.

Derrida, J. (1989). La escritura y la diferencia. Barcelona: Anthropos.

Dewey, J. (2008). El arte como experiencia. Barcelona: Paidós.

De Lucas, J. (2009). Diversidad, pluralismo, multiculturalidad. En N. Del Viso (Coord.). Reflexionessobre la diversidad (pp. 5-13). Madrid: Centro de investigación para la paz. 
Estrada, B. (2007). Recrear la espiritualidad Ancestral a través de la Danza y la Música como formas de Educación Propia. Revista Educación Pedagogía, 19 (49), 99-102.

Ferreiro, A. (2012). Una Mirada a la Investigación Cualitativa desde las artes. Revista de Artes y Humanidades, 2(4), $01-24$.

Foucault, M. (1992). El orden del discurso. Buenos Aires: Tusquets.

Freire, P. (1970). La educación como práctica de libertad. Montevideo: Tierra Nueva.

Freire, P. (2005). Pedagogía del Oprimido. Buenos Aires: Siglo XXI.

Guardo, L. (2003). Descripción y análisis de las pictografias y petroglifos en el Meta, la Orinoquia y áreas de influencia Amazónica (Tesis de licenciatura). Universidad de la Sabana, Colombia. Recuperado de https://intellectum.un isabana.edu.co/bitstream/handle/10818/5686/128882.PDF?sequence=1\&isAllowed=y

Gustin, L., Insuasty, R. y Benavides, E. (2007). La Danza y la Música como estrategia pedagógica para el fortalecimiento de la micro historia del Municipio de Cumbal (Tesis de posgrado sin publicar). Universidad de Nariño, Colombia.

Halbwachs, M. (1968). La memoria Colectiva. España: Prensas Universitarias de Zaragoza.

Henríquez, P. (2009). Oralidad y escritura en el teatro indígena prehispánico. Estudios Filológicos, (44), 81-92. doi: h ttps://doi.org/10.4067/S0071-17132009000100005

Henríquez, P. (2007, Abril). Teatro maya: Rabinal Achí o Danza del Tun. Revista Chilena de Literatura, (70), 79-108. doi: https://doi.org/10.4067/S0718-22952007000100004

Hernández, J. (2008). Adaptación de los ritmos de música andina Huayno, San Juanito ecuatoriano, Saya caporaly Tinku al set de batería (Tesis de pregrado). Universidad de Cundinamarca, Colombia.

Kauffmann, D. (1980). Manual de Arqueología Peruana. Lima: Peisa

Méndez, P. (2005, Abril). Entre el silenciamiento y la memoria. En Congreso de ULAPSI (Unión Latinoamericana de Entidades de Psicología). Congreso llevado a cabo en CINTRAS, Brasil.

Mesía, R. (2007). Contexto Ético de la Investigación Social. Lima: Inves. Educativa.

Meza, M. (2013). ¿Qué significa educación democrática? Derecho y Humanidades, (21),71 - 83. doi:https://doi.org/ $10.5354 / 0719-2517.2013 .34907$

Mignolo, W. (1992). La colonización del lenguaje y de la memoria: complicidades de la letra, el libro y la historia, 183-220. En: I. Zavala (Coord.) Discurso sobre la invención' de América. Amsterdam-Atlanta: Editions Rodopi B. V.

Ministerio de Educación. (2005). Estándares Básicos de Competencias de Lengua Castellana. Colombia: MEN.

Moliner, L., Francisco, A. y Cabedo, A. (2014). La educación para la paz en la gestión de la diversidad: el teatro del oprimido y la música comunitaria como herramientas de transformación de conflictos interculturales. En A. Calvo, C. Rodríguez e I. Haya. (Coords.). Actas del XIII Congreso Internacional de Formación del Profesorado (pp. 89-107). Santander: AUFOP-U de Cantabria.

Monsalve, J. (1995). El baile del muñeco. Colombia: Editorial Presencia.

Motos, T. y Navarro, A. (2011). Máscaras educativas detrás de la tiza. Ricerche di Pedagogia e Didattica; Journal of Theories and Research in Education, 6(1), 1-14. doi: https://doi.org/10.6092/issn.1970-2221/2180

Ortiz, K. (2011). Lasplantas medicinales en el resguardo indigena Camentsá Biyá del Municipio de Mocoa, departamento del Putumayo y la variación en el conocimiento de su uso como producto de la influencia de las diferencias socioculturales. (Tesis de pregrado). Universidad de Nariño, Colombia.

Ovelar, N. (2005). Educación, Política y Ciudadanía Democrática a través de la mirada de Paulo Freire. Revista de Pedagogia, 26(76), 1-8.

Pacheco, C. (2016). La comarca oral revisitada. Bogotá: Universidad Nacional.

Pichardo, J. (2009). Diversidades. En N. Del Viso (Coord.). Reflexiones sobre la diversidad (pp. 36-42). Madrid: Centro de investigación para la paz.

Polar, C. (2003). Escribir en el Aire. Perú: Latinoamérica editores. 
Puga, I. (2012). Teatro del Oprimido: dispositivo crítico para la Psicología Social Comunitaria. Revista SociedadEquidad, (3), 195-210. Recuperado de http://revistas.uchile.cl/index.php/RSE/article/viewArticle/18251

Radio Nacional de Colombia. (12 de julio, 2019). Por lo menos 10 grupos armados ilegales delinquen en Nariño. Radio Nacional de Colombia. Recuperado de https://www.radionacional.co/noticia/regiones/grupos-armados-ilegale s-narino

Rama, A. (2004). Transculturación Narrativa en América Latina. Buenos Aires: Siglo XXI.

Shaquiñan y Ministerio de Ambiente y Desarrollo Sostenible. (2012). Agenda ambiental en el territorio del nudo de la wuaka o de los Pastos para la permanencia de la vida y la cultura - Shaquilulo. Colombia: Min. Ambiente.

Stappen, A. (2019). Ejercicios de comunicación no violenta. Estados Unidos: Terapias Verdes.

Torres, W. (s.f). ¿Qué significa Etnoliteratura? San Juan de Pasto: Maestría en Etnoliteratura.

Vasco, C. (1994). Tres estilos de trabajo en las ciencias sociales. Bogotá: Cinep.

Zuleta, E. (2010). Educación y Democracia: un campo de combate. Bogotá: Demófilo.

Zuñiga, C. (1993). El espacio de la Etnoliteratura. Revista Sarance (17), 41-57 Recuperado de https://revistas.udena r.edu.co/index.php/rmopa/article/view/5078/5830

\section{Notas}

[1] Todos los egresados eran hombres, por lo que a lo largo del documento se habla en términos masculinos

[2]En una de las propuestas de movimientos sociales en Colombia como la del Consejo Regional Indígena del Cauca CRIC y Congreso de los Pueblos, cada pueblo tiene sus propias leyes y formas de gobierno. Las comunidades indígenas con organización social consolidada, integran en su población la toma de decisiones para la formulación de políticas propias.

[3]Categoría propuesta en Escribir en el Aire, ensayo de Cornejo Polar (2003), que se posiciona como un viaje en movimiento a través de los imaginarios regionales, donde la crítica se enfoca no sólo en los discursos marginales que sucumben en la historia cultural de América Latina, sino también en procesos de dominación simbólicos.

[4]En los estudios que Jhon Dewey (2008) hace sobre arte y experiencia, resalta la interacción del organismo con su ambiente humano así corno también físico, que incluye los materiales de la tradición, instituciones y circunstancias locales.

[5]Categoría que refiere según Freire (2005) a acciones de cambio, después de ser conscientes del problema.

[6] Vasco, C. (1994) resalta que el enfoque crítico social descubre un interés práctico y de transformación en los contextos; y, analiza los factores que impiden una comunicación liberadora.

[7]Etnográfico porque fue un trabajo de campo, donde las personas investigadoras observaron, compartieron y participaron en la vida cotidiana y eventos locales del pueblo indígena de los Pastos.

[8] Alejandra Ferreiro (2012) lo enmarca como prácticas colectivas que rompen con la rutina del tiempo y el espacio, que tienen un grado de repetición y se basan en el cuerpo como medio de expresión social y cultural.

[9]Danzas cuyo origen y transformación han ocurrido en territorio Andino, (Sur occidente colombiano, Ecuador, Perú, Bolivia y Norte Chileno), con rasgos culturales provenientes de las culturas precolombinas, africanas e hispánicas.

[10] Mesía (2007) afirma que el/la investigador/a siempre debe mantener la dignidad de los participantes.

[11]'Minga de pensamiento' refiere a construir historia, memoria y proyecciones colectivas, a través de palabras, ideas, experiencias, sentimientos y propuestas de mundo. Es una forma de saber de los pueblos indígenas de América Latina.

[12]En un texto inédito el profesor colombiano Torres (s.f. citado por Cassany, 2008), descompone el término, Etnia (éthnos), que es un modo de existencia sobre la tierra para configurar una posibilidad cultural, y literario, acepción de lo que se hace, dice, piensa y es transcrito en un cuerpo de escritura multiforme. Hacer Etnoliteratura implica experimentar su aprendizaje: aprender sus cuerpos de escritura y de lectura, en despliegue múltiple de configuraciones de lo decible e indecible. 
[13]Se promovió una estrategia pedagógica y didáctica dirigida al desarrollo de competencias comunicativas, que refleja según los Estándares Básicos de Competencias de Lengua (Ministerio de Educación, 2005), tres factores de competencia: Producción textual, Medios de comunicación y otros sistemas simbólicos, y Ética de la comunicación.

[14]Según Daniel Cassany (2008) el concepto de crítico ha avanzado históricamente, tomando partida con los académicos de la Escuela de Frankfurt, en donde se sostenía desde el marxismo que la sociedad está agobiada de vicios que sólo pueden "curarse” con una transformación radical de teoría- práctica. Paulo Freire (1970) fundamenta la Literacidad Crítica, afirmando que la escritura debe ser vínculo social, donde los saberes ayuden a cambiar el entorno.

[15]Se usan seudónimos en todos los casos para proteger la identidad de las personas, en su mayoría menores de edad.

[16]Mary, asistente al taller (2016), la describe como el alma en pena de una mujer o de una bruja, que quedó sola y abandonada al morir el amor de su vida; enloqueció de pena y rabia, y por ello decidió vengarse de todo hombre. Su presencia es señal de que algo malo va a pasar, cuando la ven dentro de una casa, algo grave viene. Suele asustar a los borrachos, llevarlos al cementerio o al río para ahogarlos.

[17]La abuelita de Deis y Deib -hermanos Colimba- asistentes al taller (2016) les contó para su tarea, que se trata de un espanto que en vida fue cacica, quiso una figura matriarcal para la comunidad y por ello fue quemada. Ahora muele a los hombres con dos rocas y los devora.

[18] Monsalve (1995) lo resalta como un teatro estratégico, que permite estudiar la población, agenciar sus procesos de memoria y abrir espacios culturales en las comunidades.

[19] Guardo (2003) fortalece la mirada de los símbolos en las comunidades indígenas, al enfocarse en la Orinoquía colombiana para tomar los pictogramas y petroglifos como la variedad en formas, ritmos y temas que afectan las estéticas y la percepción del mundo desde los sentidos y expresiones del lenguaje.

[20]El chapil es una bebida alcohólica artesanal que se extrae de la caña de azúcar, la suelen consumir los pueblos indígenas y campesinos del sur andino de Colombia y de Ecuador, se usa no sólo para las celebraciones sino también para algunos rituales de limpieza espiritual. Según la región, su uso gastronómico presenta algunas variantes, en algunos lugares del departamento de Nariño como Cumbal, Guachucal, Túquerres, Ipiales, Pasto y la Laguna de La Cocha, se utiliza popularmente por ejemplo, para preparar infusión de canela o canelazos y para hacer hervidos, bebida caliente con fruta (mora, lulo, piña, maracuyá), agua, panela y este licor.

[21]Procede del quechua, significa Fiesta del sol.

[22]El Liceo de la Universidad de Nariño es un prestigioso colegio de la ciudad de San Juan de Pasto, (sur de Colombia), que se ha distinguido por ocupar los primeros puestos en las Pruebas Saber a nivel de educación media y secundaria.

[23]Categoría que refiere el texto de Vasco (1994) para enmarcar una característica del enfoque investigativo de las Ciencias Sociales. Así mismo, Freire (2005) la vislumbra como característica en la Pedagogía del Oprimido.

[24]Género narrativo Latino que en las últimas décadas ha impulsado nuevas estéticas de las comunidades latinoamericanas.

[25] AGRADECIMIENTOS: Al agua que fluye desde el volcán Cumbal y a sus frescos aires, a las energías que cuidaron todo el proceso creador, a la magia de la vida, al padre fuego... Especialmente a las personas jóvenes de la Vereda Cuetial, a sus padres, a sus madres y a la comunidad del pueblo indígena de los Pastos. A la Institución Educativa Sagrado Corazón de Jesús. A la Universidad de Nariño y a la Maestría en Etnoliteratura de la misma universidad por permitir la formación de seres críticos.

[26]Según la Radio Nacional de Colombia (2019) el departamento de Nariño está ubicado en una zona estratégica, pues está en la frontera con Ecuador, tiene salida al océano Pacífico, tiene acceso al norte del país por la cordillera y las montañas del sur del Cauca, por ello es uno de los territorios más disputados por los grupos ilegales dedicados al narcotráfico, la Defensoría del Pueblo ha señalado que es preocupante que durante 2019 se hayan registrado 14 desplazamientos masivos y que sean múltiples los asesinatos a excombatientes de las Fuerzas Armadas Revolucionarias de Colombia FARC y a lideres sociales. 